\title{
TANGGUNG GUGAT PERDATA BANK TERHADAP KLAIM BANK GARANSI YANG DIKELUARKAN
}

\author{
Youngky Yudho Pramono \\ Program Magister Kenotariatan Fakultas Hukum Universitas Brawijaya \\ Jl. MT. Haryono No 169; Malang; 65145; Indonesia; (0341) 553898 \\ youngky_cow@yahoo.co.id
}

\begin{abstract}
Stable economic growth, accompanied by equitable development and the level of public confidence in the government over the development of infrastructure it works, not only the government alone the private sector also participate play a role in building the country. This writing has the purpose of knowing how the Bank's Liability Against Bank Guarantee Claims if the guaranteed party (contractor) performs a default, to identify and analyze the constraints faced by the guarantor (bank) to sue and collect the assured (contractor) after obtaining Bank Guarantee claims from the recipient of the guarantee (employer). This type of research uses a kind of juridical-empirical research which means this study describes the facts that occur in the field and know the effectiveness of the validity of positive law in society. Empirical research is a research on the implementation of a rule of law, especially the Law related to Bank Guarantee. This writing focuses on the issue of civil liability of banks against bank guarantee claims, if the guaranteed party (contractor / contractor) to do wanprestasi. Barriers facing banks to sue and collect are secured after obtaining bank guarantee claims.
\end{abstract}

Keywords: Accountabilit, Bank Guarantee, the Bank Guarantee Claim.

\begin{abstract}
Abstrak
Pertumbuhan ekonomi yang stabil, diiringi pembangunan yang merata serta tingkat kepercayaan masyarakat terhadap pemerintah atas pembangunan infrastruktur yang dikerjakannya, bukan hanya pemerintah saja pihak swasta pun juga ikut serta berperan dalam membangun negeri. Penulisan ini mempunyai tujuan Untuk mengetahui Bagaimana Tanggung Gugat Bank Terhadap Klaim Bank Garansi jika pihak terjamin (kontraktor) pemborong) melakukan wanprestasi, untuk mengidenfikasi dan menganalisis hambatan yang dihadapi pihak pemberi jaminan (bank) untuk menggugat dan menagih terjamin (pemborong/kontraktor) setelah memperoleh klaim Bank Garansi dari pihak penerima jaminan (pemberi pekerjaan). Jenis Penelitian ini menggunakan jenis penelitian yuridis-empiris yang artinya penelitian ini mendeskripsikan fakta yang terjadi di lapangan dan mengetahui efektifitas berlakunya hukum positif di masyarakat. Penelitian empiris merupakan penelitian terhadap pelaksanaan suatu aturan perundang-undangan, khususnya Undang-undang yang terkait dengan Bank Garansi. Penulisan ini fokus pada persoalan tanggung jawab perdata bank terhadap klaim bank garansi, jika pihak terjamin (kontraktor/pemborong) melakukan wanprestasi. Hambatan yang dihadapi bank untuk menggugat dan menagih terjamin setelah memperoleh klaim bank garansi.
\end{abstract}

Kata kunci: Bank Garansi, Klaim Bank Garansi, Tanggung Gugat. 


\section{Tanggung Gugat Perdata Bank terhadap Klaim Bank Garansi Yang Dikeluarkan}

Youngky Yudho Pramono

\section{Pendahuluan}

Tugas pemerintah adalah sebagai perencana atas pembangunan infrastruktur yang kokoh dan handal dimana pemerintah harus memilih kontraktor atau pemborong yang terpercaya tentunya, agar proyek yang dikerjakan sesuai apa yang di inginkan dan sesuai dengan kebutuhan masyarakat umum maka diperlukannya pemborong yang dapat terpercaya, untuk itu pemerintah dalam hal ini disebut pihak pemberi pekerjaan dan pemborong atau bisa disebut penerima pekerjaan, pemberi pekerjaan mensyaratkan dalam proyeknya adanya sebuah jaminan, agar pihak pemberi pekerjaan yakin bahwa proyek yang dikerjakan oleh pemborong tersebut benar-benar sesuai dengan apa yang diinginkan.

Terlebih bahwa maraknya tindakan yang menyimpang dari pengerjaan suatu proyek pemerintah seperti tindakan pencucian uang, korupsi dan lain sebagainya sehingga pemerintah tidak dirugikan untuk itu Lembaga keuangan harus melakukan upaya pemeriksaan terhadap nasabah, termasuk mengidentifikasi dan memeriksa identitas nasabahnya, pada saat: 1) membuka rekening; 2) melakukan transaksi-transaksi tertentu: a. dengan jumlah diatas batas yang ditentukan; atau b. yaitu transfer wire dengan ketentuan termasuk dalam catatan interpretasi Rekomendasi Khusus VII; 3) terdapat dugaan terjadinya pencucian uang atau pendanaan teroris; atau 4) lembaga keuangan memiliki keraguan atas autentikasi atau kecukupan data identifikasi nasabah yang diperoleh sebelumnya (Amrullah, 2015).

Jaminan Bank (Bank Garansi) adalah pernyataan tertulis yang dikeluarkan oleh bank atas permintaan nasabahnya (terjamin) untuk menanggung risiko tertentu (penggantian kerugian) yang timbul bila pihak terjamin tidak dapat memenuhi kewajibannya (wanprestasi) kepada pihak yang menerima jaminan. Borgtocht merupakan istilah dalam hukum perdata yang bisa digunakan sehubungan dengan hukum jaminan. Jaminan itu sendiri ada dua jenis, yaitu jaminan kebendaan dan jaminan perorangan.

Hal ini sebagaimana dijelaskan Sri Soedewi Masjchoen sofwan (2007), bahwa Bank Garansi merupakan bagian dari Borgtocht namun yang membedakan adalah Borgtocht jaminan perorangan yang berbentuk Asesoir sedangkan Bank Garansi jaminan yang bersifat pokok. Bank Garansi adalah salah satu bentuk penyederhanaan/pengembangan dari Borgtocht.

Berikut ini adalah tabel mekanisme penerbitan Bank Garansi yang di lakukan oleh bankbank pada umumnya, berikut dengan penjelasannya.

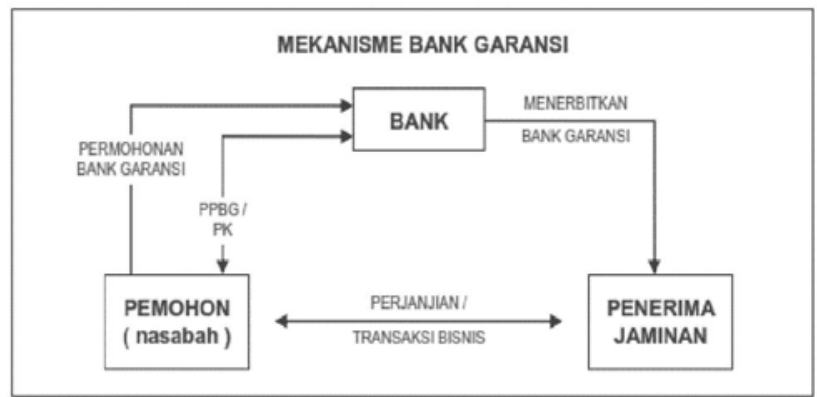

Bagan 1, Mekanisme Bank Garansi

Sumber: BCA Learning Center, Produk Kredit Penjaminan, Desember 2011.

Menurut Thomas Suyatno (2003), salah satu fungsi dari Bank Garansi yang umum digunakan adalah untuk melaksanakan pembangunan proyek diadakan perjanjian antara pemborong dan pemberi pekerjaan pembangunan proyek (bisa pemerintah atau pihak swasta). Pihak pemberi pekerjaan menginginkan adanya bank garansi untuk menutupi pekerjaan pembangunan proyek. Hal ini dilakukan untuk mencegah kemungkinan timbulnya resiko, yang terjadi akibat pemborong melakukan wanprestasi sebelum pembangunan proyek diselesaikannya.

Dasar hukum dari Bank Garansi dapat di simpulkan pada Kitab Undang-Undang Hukum 
Perdata pada pasal 1820 sampai dengan pasal 1850, perjanjian tersebut bisa dikatakan dengan perjanjian kerjasama. Perjanjian tersebut dapat menjamin kelangsungan Bank Garansi, maka penanggung mempunyai hak istimewa yang diberikan undangundang, yaitu untuk memilih salah satu dari pasal 1831 dan pasal 1832 KUHPerdata.

Bank Garansi merupakan produk jasa Bank dan bukan kegiatan utama dari Bank sehingga peraturan Bank Garansi tidak diatur dalam UndangUndang Republik Indonesia Nomor 10 Tahun 1998 Tentang Perbankan, Bank Garansi diatur secara khusus oleh Gubernur Bank Indonesia Nomor 23/ 88/ KEP/DIR, Tanggal 18 Maret 1991, Bank Garansi mempunyai tujuannya untuk memperlancar kegiatan transaksi bisnis.

Berdasarkan latar belakang dan isu hukum diatas untuk mengetahui lebih lanjut mengenai tanggung gugat bank dan kendala apa yang dihadapi oleh pihak bank sebagai pemberi jaminan dalam menagih terjamin setelah memperoleh klaim Bank Garansi dari pihak penerima jaminan, maka penulis tertarik untuk menulis dengan fokus persoalan yaitu bagaimanakah Tanggung Gugat Bank Terhadap Klaim Bank Garansi, ketika pihak terjamin (kontraktor/ pemborong) melakukan wanprestasi dan apakah hambatan yang dihadapi pihak penjamin (Bank), untuk menggugat dan menagih terjamin (pemborong/ kontraktor) setelah memperoleh klaim Bank Garansi dari pihak penerima jaminan (pemberi pekerjaan).

\section{Pembahasan}

\section{A. Tugas dan Wewenang Perkreditan BCA Malang}

Selain menerapkan fisi, misi dan tata nilai dalam melayani nasabahnya, dengan dipimpin oleh Kepala Kantor BCA Malang dalam perkembangannya menjadi semakin pesat karena didukung Sumber Daya Manusia yang memadahi, BCA juga mempunyai sistem struktur organisasi yang berfungsi untuk mempermudah pengawasan dan tanggung jawab kerja pada setiap pegawai BCA. Organisasi perkreditan ini menampung aktivitas dari proses pengolahan kredit yang menghasilkan keputusan persetujuan kredit sampai dengan realisasi kredit, dimana keputusan tersebut diberikan oleh pejabat pemutus sesuai dengan wewenang yang dimilikinya dan/atau ditetapkan oleh Direksi. Suatu proses pemberian kredit melibatkan aktivitas beberapa unit kerja sehingga diperlukan suatu organisasi kredit yang sistematis sehingga setiap unit kerja dapat saling bekerjasama dengan baik dan berkesinambungan (BCA Learning Center, 2011).

\section{B. Tanggung Gugat Bank Terhadap Klaim Bank Garansi, Jika Pihak Terjamin (Kontraktor/ Pemborong) Melakukan Wanprestasi}

1. Jenis Bank Garansi (Bank Garansi Tanpa Plafon)

Bank Garansi (BG) adalah non cash fasility dalam bentuk warkat. Bank Garansi diterbitkan oleh bank sebagai garansi yang mengakibatkan adanya kewajiban membayar terhadap pihak yang menerima garansi apabila pihak terjamin wanprestasi. Bank Garansi berdasarkan jenis penggunaannya dibedakan dalam 6 jenis, yaitu (BCA Learning Center, 2011).

1. Bid Bond/ Jaminan Tender adalah Bank Garansi untuk menjamin bahwa kontraktor atau peserta tender sebagai pemohon tidak akan mengundurkan diri selama masa tender berlangsung dan bersedia menandatangani kontrak setelah ditunjuk sebagai pemenang tender;

2. Advance Payment Bond/ Jaminan Uang Muka adalah Bank Garansi untuk menjamin bahwa pelaksanaan proyek akan melaksanakan pekerjaan/ kewajibannya setelah menerima uang muka pekerjaan dari pemberi pekerjaan sebagai pemilik proyek (bouwheer) untuk mencegah hilangnya uang muka karena pemegang proyek cidera janji; 


\section{Tanggung Gugat Perdata Bank terhadap Klaim Bank Garansi Yang Dikeluarkan}

Youngky Yudho Pramono

3. Performance Bond (Bank Garansi Pelaksana) adalah Bank Garansi untuk menjamin bahwa penerima pekerjaan sebagai pemohon akan menyelesaikan pekerjaan yang diserahkan pemberi kerja/ pemilik pekerjaan. Nilai dan waktu penyerahan dapat disesuaikan dengan nilai keseluruhan proyek atau pertemin proyek;

4. Bank Garansi Pemeliharaan (Maintenance Bond/Retention Bond) adalah Bank Garansi untuk menjamin bahwa pelaksanaan proyek sebagai pemohon akan melaksanakan pemeliharaan terhadap proyek yang telah selesai selama masa warranty atau pemeliharaan berlangsung;

5. Bank Garansi Pembayaran adalah Bank Garansi untuk menjamin pemberi kerja/ pemilik pekerjaan/ agen/ dealer/ distributor sebagai pemohon akan melakukan pembayaran kepada pelaksana atau penerima pekerjaan/ produsen/ pedagang besar sebagai Beneficiary sebagai kontak/ perjanjian dan kontrak;

6. Custom Bond adalah Bank garansi untuk menjamin bahwa pemilik barang/ perusahaan/ pabrik sebagian terjamin akan melunasi penanggungan pembayaran Bea masuk atas barang yang dikeluarkan dari pelabuhan atau pembayaran pita cukai dan lain-lain kepada kantor Bea Cukai/pajak sebagai penerima jaminan.

Memberikan fasilitas Bank Garansi adalah kewajiban Bank untuk menjamin Penerima Jaminan, Bank Garansi Tanpa Plafon adalah fasilitas Terjamin (pemohon) yang tidak memiliki plafon sehingga setiap akan memohon untuk menerbitkan bilyet bank garansi Terjamin harus mengajukan permohonan Bank Garansi terlebih dulu untuk kemudian dianalisa, disetujui, dan menandatangani Perjanjian Penerbitan Bank Garansi.

Menurut Kepala Operasi Kredit BCA Malang, dasar hukum diterbitkannya Bank Garansi adalah Surat Keputusan Direksi Bank Indonesia Tentang Pemberian Garansi Oleh Bank nomor 23/88/KEP/DIR tanggal 18 Maret 1991, jika surat keputusan tersebut dicabut oleh Bank Indonesia maka penerbitan Bank Garansi tidak lagi berlaku, karena tidak ada lagi dasar yang menompangnya (Kepala Operasi Kredit, 2017). Kabag Dokumentasi Kredit menambahkan, pada penerbitan Bank Garansi persyaratan dokumen adalah hal yang penting. Karena berkaitan dengan legalitas dari diterbitkan sampai proses klaim Bank Garansi, Bank Garansi memerlukan dokumen-dokumen yang sifatnya mengikat, karena tanpa dokumen yang sah maka kekuatan hukum dari Bank Garansi tersebut cuma akan menjadi kertas sertifikat saja (Kepala Dokumentasi Kredit, 2017), Selanjutnya Account Officer akan mengirimkan dokumen yang diterima dari pemohon atau terjamin ke Fungsi Dokumentasi Kredit melalui Petugas Penerimaan Dokumen untuk diproses lebih lanjut.

Terdapat syarat yang harus dipenuhi sebelum Bank Garansi tersebut di berikan kepada Penerima jaminan, syaratnya sebagai berikut: a. Terjamin (pemohon) telah menandatangani Perjanjian Penerbitan Bank Garansi (PPBG);

b. Kontrak kerja antara pihak yang dijamin dengan penerima BG.

Setelah mengetahui proses pengikatan sampai penerbitan Bank Garansi yang panjang, pihak BCA masih mempunyai satu tanggung jawab penyelesaian, Penyelesaian Bank Garansi dapat dilakukan jika jangka waktu PK/PPBG telah berakhir dan tidak ada klaim secara tertulis dari pihak penerima Bank Garansi kepada bank atau pada saat asli bank garansi dikembalikan oleh Terjamin tanpa ada klaim. Adapun penyelesaian pada Bank Garansi yang di keluarkan terdapat 2 (dua) macam penyelesaian, yaitu penyelesaian dengan tanpa klaim dan penyelesaian dengan klaim, berikut adalah 
langkah penyelesaian tanpa klaim dan penyelesaian dengan klaim (Panduan Kerja Fungsi Operasi Kredit BCA, 2007).

Berikut adalah syarat-syarat yang harus dipenuhi pada saat dilakukan penyelesaian BG (tanpa ada klaim). a. Masa klaim telah berakhir, b. Tidak ada klaim secara tertulis kepada bank dari pihak penerima Bank Garansi, c. Asli warkat telah diterima kembali oleh BCA dengan catatan apabila sebelum jatuh tempo Terjamin mengembalikan asli Bank Garansi, maka harus dilengkapi dengan surat pernyataan dari penerima bank garansi bahwa kontrak sudah selesai.

2. Pembayaran Tuntutan Ganti Rugi

Pembayaran ganti kerugian akan diberikan jika, Pengawas Proyek/Satuan Kerja/Pemimpin Proyek yang bersangkutan wajib dengan segera memberitahukan secara tertulis kejadian tersebut kepada BCA (penjamin). BCA (penjamin) akan membayar ganti rugi kepada Pengawas Proyek/Satuan Kerja/Pemimpin Proyek apabila telah terbukti menimbulkan kerugian yang disebabkan oleh wanprestasi, kelalaian atau kegagalan Terjamin (kontraktor/ pemborong).

Hal-hal yang dapat dianggap sebagai bukti wanprestasi, kelalaian atau kegagalan Terjamin (kontraktor/pemborong) tersebut antara lain (Panduan Kerja Fungsi Operasi Kredit BCA, 2007).

a. Pernyataan resmi dari Pengawas Proyek/ Satuan Kerja/Pemimpin Proyek mengenai wanprestasi, kelalaian atau kegagalan Terjamin (kontraktor/ pemborong);

b. Pengakuan tertulis dari Terjamin (kontraktor/pemborong) yang bersangkutan mengenai wanprestasi, kelalaian atau kegagalannya tersebut;

c. Dokumen-dokumen atau petunjuk-petunjuk lainnya yang dapat dipergunakan sebagai bukti wanprestasi, kelalaian atau kegagalan Terjamin (kontraktor/pem- borong).

Pengajuan tuntutan ganti rugi harus dilengkapi dengan Bilyet Bank Garansi asli serta dokumen-dokumen pendukung lainnya. Batas jumlah ganti rugi yang menjadi tanggung jawab BCA (penjamin), setinggi-tingginya adalah sebesar jumlah nilai yang tertulis di Bilyet Bank Garansi.

Selanjutnya BCA (penjamin) telah membayarkan ganti rugi atas tuntutan Pengawas Proyek/Satuan Kerja/Pemimpin Proyek terhadap Klaim Bank Garansi yang dimaksud, maka berdasarkan Perjanjian ganti rugi atau Perjanjian Pemberian Bank Garansi (PPBG), BCA (penjamin) berhak menjalankan hak istimewanya yaitu hak Subrogasi sesuai dengan ketentuan Kitab Undang-undang Hukum Perdata pasal 1400 serta untuk esekusinya pada pasal 1831 dan pasal 1832 KUHPerdata.

Hak Subrogasi adalah penggantian atau peralihan hak oleh seorang pihak ketiga yang membayar kepada kreditur, sebelum melaksanakan haknya BCA (penjamin) harus memperhatikan semua dokumen-dokumen telah lengkap dan memenuhi ketentuan yang berlaku. Pasal 1831 dan pasal 1832 KUHPerdata adalah hak istimewa yang dimiliki oleh BCA (penjamin) untuk melunasi klaim atau tuntutan pihak Penerima Jaminan (pemegang Bilyet Bank Garansi). Hak subrogasi yang dimaksud pada pasal 1400 dan esekusinya pada pasal 1831 dan pasal 1832 KUHPerdata adalah BCA (Penjamin) mempunyai hak untuk menyita dan menjual jaminan Terjamin (Pemborong/ Kontraktor) untuk melunasi tuntutan atau klaim dari Penerima jaminan (pemegang Bilyet Bank Garansi).

Menurut Kepala Operasi Kredit BCA Malang, ada 2 (dua) jenis penguasaan hak subrogasi atau Angunan Yang Diambil Alih (AYDA) yaitu (Kepala Operasi Kredit, 2017). 
a. Penguasaan semua bentuk tabungan yang dijaminkan atau barang berharga yang dapat segera dicairkan kemudian memberikan ganti rugi sesuai nominal yang dialami penerima jaminan dan sisanya akan dikembalikan kepada Terjamin;

b. Penguasaan Surat berharga, biasanya dalam hal ini Bank akan mengganti sementara kerugian dari penerima jaminan kemudian setelah AYDA terjual sisa uang akan dikembalikan.

Ada Dua macam penyelesaian Bank Garansi

1. Penyelesaian tanpa ada klaim:

a) Masa berlaku Bank Garansi berakhir.

b) Tidak ada klaim secara tertulis.

c) Asli warkat telah diterima kembali oleh BCA.

2. Penyelesaian dengan adanya klaim:

a) Pernyataan resmi dari penerima jaminan.

b) Pengakuan tertulis dari Terjamin.

c) Dokumen atau petunjuk lainnya yang dapat dipergunakan sebagai bukti wanprestasi.

\section{Hambatan yang Dihadapi Bank Untuk Menggugat dan Menagih Terjamin Setelah Memperoleh Klaim Bank Garansi}

1. Klaim Dari Pihak Penerima Jaminan Terhadap BCA

Arif Hidayat selaku Kepala Unit Layanan Pengadaan Universitas Brawijaya Malang (2016). Memberikan keterangannya mengenai kelalaian pihak terjamin saat menjalankan kewajibannya, kelalaian terjamin tersebut dituliskan pada perjanjian kontrak kerja yang dimiliki oleh ULP Universitas Brawijaya point ke 43 yang disebut dengan Keterlambatan Pelaksanaan Pekerjaan dan Kontrak Kritis.

Point 43.1 menerangkan apabila penyedia terlambat melaksanakan pekerjaan sesuai jadwal, maka PPK harus memberikan peringatan secara tertulis atau dikenakan ketentuan ten- tang kontrak kritis. Ada 3 kategori kontrak dinyatakan kritis (point 43.2) apabila (Dokumen Pengadaan Pekerjaan Kontruksi Universitas Brawijaya, 2014).

1. Dalam periode I (rencana fisik pelaksanaan $0 \%-7 \%$ dari kontrak), selisih keterlambatan antara realisasi fisik pelaksanaan dengan rencana pelaksanaan lebih besar $10 \%$;

2. Dalam periode II (rencana fisik pelaksanaan $70 \%-100 \%$ dari kontrak), selisih keterlambatan antara realisasi fisik pelaksanaan lebih besar 5\%;

3. Dalam periode III (rencana fisik pelaksanaan 70\% - 100\% dari kontrak), selisih keterlambatan antara realisasi fisik pelaksanaan dengan rencana pelaksanaan kurang dari 5\% dan akan melampaui tahun anggaran berjalan.

Atas dasar perjanjian Pengadaan Pekerjaan Konsruksi itulah pihak penerima jaminan (ULP) melakukan klaim Bank Garansinya terhadap BCA, selanjutnya BCA menjalankan fungsinya sebagai Penjamin untuk menagih atau menggugat Terjamin.

2. Kebijakan BCA dalam Pengelolaan AYDA Terdapat 2 (dua) jenis Agunan Yang Diambil Alih (AYDA), yaitu anggunan yang sifatnya cepat dicairkan dan anggunan yang sifatnya memerlukan waktu yang tidak sebentar untuk pencairannya (dalam bahasa hukum bisa disebut benda bergerak dan tidak bergerak). Menurut Ignatia juliana Kepala Dokumentasi Kredit BCA Kanwil VII, mengatakan bahwa ada penanganan khusus untuk AYDA yang sifatnya memerlukan waktu yang tidak sebentar itu, yaitu dengan cara negosiasi terlebih dahulu terhadap pemilik anggunan atau Terjamin, apakah AYDA akan dijual atau AYDA akan ditebus (Kepala Dokumentasi Kredit, 2017). 
Menurut Standart Operasional Prosedur kerja (SOP) BCA, Agunan Yang Diambil Alih (AYDA) adalah agunan kredit/ aset debitur dan/atau penjamin yang diambilalih oleh Bank, baik melalui pelelangan maupun di luar pelelangan, berdasarkan penyerahan sukarela oleh pemilik agunan dalam hal debitur tidak dapat memenuhi kewajibannya kepada Bank. Pengambil alihan agunan kredit/ aset debitur dan/atau penjamin baik melalui eksekusi maupun kompensasi harus dilakukan atas nama BCA (Kebijakan Perkreditan Bank PT Bank Central Asia Tbk, 2010).

Pengambilalihan agunan kredit/aset debitur dan/atau penjamin melalui eksekusi dapat dilakukan langsung atas nama BCA atau dengan menggunakan akta de command (Surat Pernyataan bahwa pembelian tersebut dilakukan untuk pihak lain) dan setelah lewat 1 (satu) tahun harus dilakukan balik nama kepada BCA. Pengambilalihan agunan kredit/ aset debitur dan/atau penjamin melalui kompensasi tanpa menggunakan Akta Jual Beli (AJB) kepada BCA, dapat pula dilakukan dengan akta Perjanjian Pengikatan Jual Beli (PPJB) dan Akta Kuasa Menjual dimana jika dalam waktu 1 (satu) tahun agunan belum juga terjual maka harus dilakukan balik nama kepada BCA.

Pengambilalihan AYDA dengan menggunakan akta de command (Surat Pernyataan bahwa pembelian tersebut dilakukan untuk pihak lain) maupun kompensasi tanpa menggunakan AJB kepada BCA dapat dilakukan sepanjang ada keyakinan bahwa tidak ada risiko sita jaminan dari pihak lain ataupun hal lain yang akan menyulitkan/ menghambat pengalihan AYDA ke atas nama BCA/ pihak lain.

Sesuai dengan PBI Nomor 7/2/PBI/ 2005 tanggal 20 Januari 2005, maka Bank wajib melakukan upaya penyelesaian terhadap AYDA yang dimiliki, antara lain dengan cara memasarkan dan menjual kembali barang sitaan. Bank wajib mendokumentasikan upaya penyelesaian AYDA. Tunggakan bunga yang diselesaikan dengan AYDA tidak dapat diakui sebagai pendapatan sampai dengan adanya realisasi (penjualan) AYDA. Berikut ini adalah kebijakan BCA dalam pengelolaan AYDA (Kebijakan Perkreditan BCA, 2010).

Penjelasan kebijakan perkreditan BCA untuk menyelesaikan AYDA diperlukan pertimbangan khusus dari pihak yang terkait, hal ini dimaksudkan untuk menghindari terjadinya sengketa antara Terjamin dan Penjamin sehingga para pihak tidak dirugikan dengan penjualan AYDA.

3. Larangan penjualan Agunan yang Diambil Alih Kemudian Staf Dokumentasi Kredit dari Bank Central Asia Malang, menambahkan mengenai larangan penjualan AYDA. BCA dilarang menjual AYDA yang dimilikinya kepada pihakpihak yang memenuhi salah satu kriteria berikut ini (Staf Dokumentasi Kredit, 2017). Pejabat dan staf yang terlibat dalam persetujuan pemberian kredit maupun pengambilalihan AYDA;

1. Pejabat dan staf yang terlibat dalam keputusan penjualan AYDA;

2. Staf BCA yang terlibat dalam tugas pengelolaan AYDA;

3. Suami/ istri/ orang tua/ mertua/ anak/ saudara kandung dari salah satu angka 1 sampai dengan Nomor 3 di atas.

Selanjutnya untuk keperluan pengawasan, TPKK atau UBKK atau KKK wajib melaporkan keadaan AYDA secara triwulanan kepada BPK.

4. Hambatan Internal dan Eksternal Dalam Penagihan Bank Garansi

Terdapat dua jenis hambatan yang dihadapi oleh BCA dalam menggugat dan menagih terjamin saat klaim Bank Garansi diajukan, yaitu hambatan internal dan hambatan eksternal. Hambatan internal adalah hambatan yang di- 
hadapi oleh pihak bank dari sektor internal bank itu sendiri, antara lain:

1. Proses birokasi antar devisi BCA membutuhkan waktu dan energi yang tidak sebentar karena sering terjadi perbedaan pendapat;

2. Proses pencarian dokumen-dokumen yang terkait dengan AYDA membutuhkan waktu yang ektra, disisi lain para staf harus bekerja tidak hanya untuk pencarian dokumen saja;

3. BCA harus mengeluarkan biaya tambahan untuk melengkapi dokumen yang terkait dengan legalitas AYDA, biaya tersebut diambil dari uang kas BCA.

Keterbatasannya dari sisi Sumber Daya Manusia (SDM) dan biaya ektra yang harus ditanggung oleh BCA menjadi persoalan yang harus diselesaikan oleh pihak BCA itu sendiri, tanpa harus membebankan biaya-biaya tambahan terhadap Terjamin. Hal ini termasuk resiko yang dihadapi oleh BCA ketika adanya klaim Bank Garansi yang di ajukan, demi menjaga integritas kerja maka karyawan BCA dituntut untuk bekerja dengan ekstra agar semua persoalan dapat diselesaikan tanpa harus ada yang dirugikan.

Hambatan eksternal adalah hambatan yang datangnya dari sektor luar, hambatan tersebut bisa datang dari nasabah/ terjamin dan peraturan pemerintah, antara lain:

1. Ketika proses penagihan terhadap Terjamin atas klaim Bank Garansi penerima jaminan, terjamin dengan sengaja mengulur waktu, perjanjian Bank Garansi menegaskan jika dalam kurun waktu 14 hari tidak memberikan pernyataan secara tertulis kepada bank maka bank akan memberikan surat peringatan, kemudian setelah 30 hari bank tidak mendapatkan jawaban dari pihak terjamin maka bank akan menjadikan jaminan tersebut menjadi AYDA (khusus terjamin yang menjaminkan benda tidak bergerak);

2. Secara komersial pelaksanaan eksekusi membutuhkan tenaga dan biaya khusus, termasuk birokasi dalam proses peradilan, disini bank perlu perlindungan hukum untuk mengeksekusi AYDA.

5. Teori Perlindungan Hukum Terhadap Bank Atas Bank Garansi

Menurut Satjipto Rahardjo, perlindungan hukum memberikan pengayoman terhadap hak asasi manusia yang dirugikan orang lain dan perlindungan itu di berikan kepada masyarakat agar dapat menikmati semua hak-hak yang diberikan oleh hukum (Rahardjo, 2006). Perlindungan hukum dalam Bank Garansi memberikan pengayoman terhadap hak asasi manusia dalam artian yang sempit adalah Penerima Jaminan yang dirugikan oleh Terjamin dan perlindungan itu di berikan kepada Penanggung (bank) agar dapat memberi kepastian terhadap Penerima Jaminan yang semua hak-haknya diberikan oleh hukum.

6. Ringkasan Prosedur Penyelesaian Bank Garansi Dengan Adanya Klaim

Berikut ini adalah ringkasan prosedur dan tahapan penyelesaian Bank Garansi yang dilakukan oleh tim penyelesaian AYDA di kantor BCA Malang:

Dengan adanya kebijakan penyelesaian dengan adanya klaim dalam bagan di atas membantu dalam penyelesaian sengkeya berkaitan dengan kredit dengan pemborong. Penyelesaian permasalahan tersebut juga suatu bentuk perlindungan hukum kepada konsumen. 


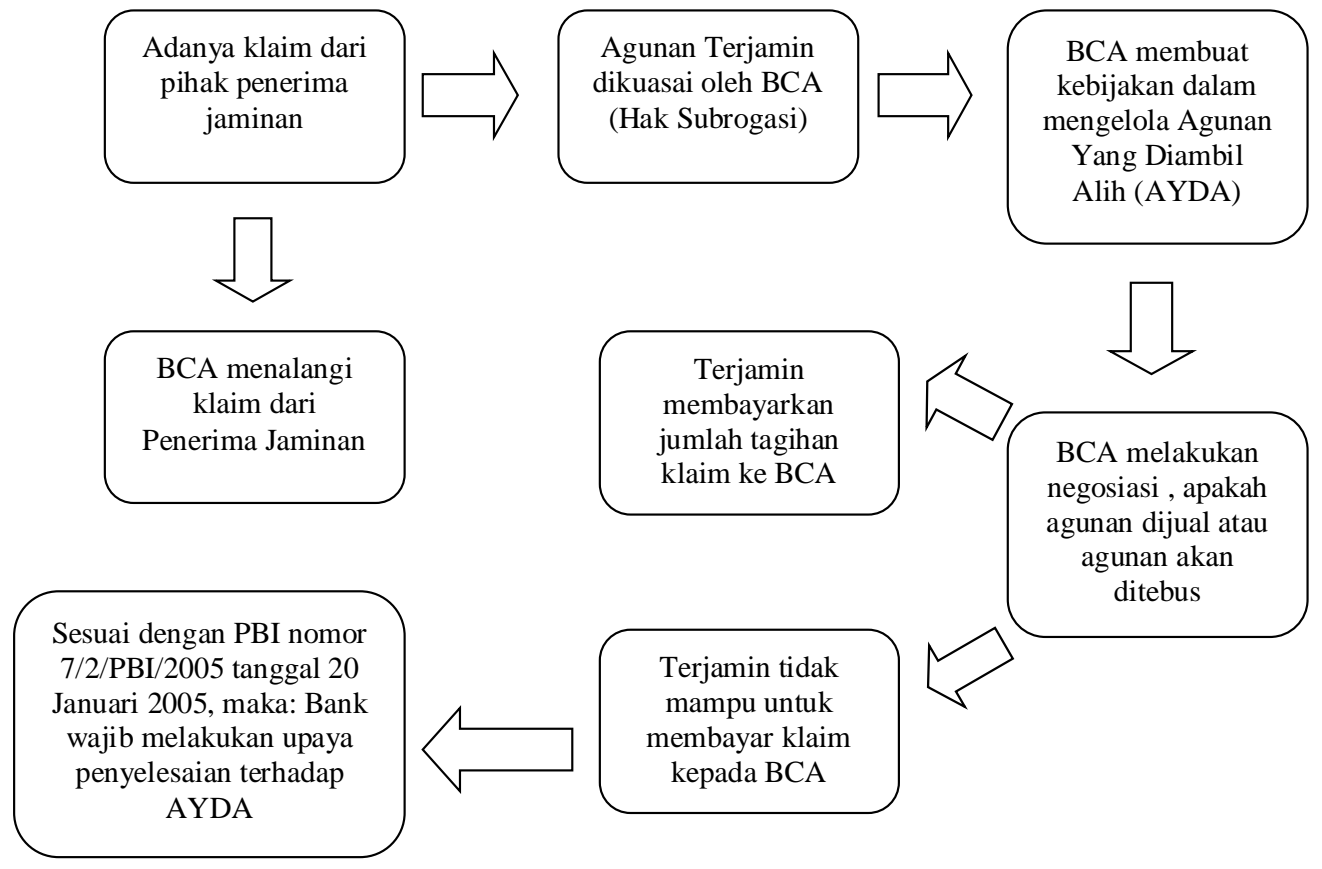

Bagan 2, Penyelesaian Dengan Adanya Klaim

Sumber: Kebijakan Perkreditan Bank PT Bank Central Asia Tbk, Desember 2010.

\section{Kesimpulan}

Terdapat 3 kesimpulan untuk pihak BCA dalam penerbitan Bank Garansi, yaitu Pertama, Bank dalam Penerbitan Bank Garansi mempunyai tanggung jawab yang cukup besar bagi para pihak, karena Bank harus bisa mempertanggung jawabkan dan menyelesaikan klaim Bank Garansi yang diterima, tanpa harus merugikan setiap pihak. Kedua, Resiko yang dialami oleh bank terkadang tidak sesuai dengan pendapatan dari jasa penerbitan Bank Garansi, karena resiko pemberian Bank Garansi sama seperti resiko pemberian kredit pada umumnya. Ketiga, Pihak Bank dituntut harus paham Hukum, khususnya Hukum Perdata untuk menyelesaikan masalah perdata dalam setiap kasus yang ditangani.

\section{DAFTAR PUSTAKA}

Amrullah, M. 2017. Pencegahan Tindak Pidana Pencucian Uang Melalui Jasa Gatekeeper Di Indonesia. Jurnal Cakrawala Hukum, 6(1), 77-88. doi:10.26905/idjch.v6i1.687.

BCA Learning Center, Adminitrasi Kredit, Jakarta, Mei 2010.

BCA Learning Center, Aspek Sumber Daya Manusia Dan Manajemen. Jakarta. Maret 2011.

BCA Learning Center. Dasar-dasar Analisa Kredit. Jakarta. Maret 2011.

BCA Learning Center. Pengenalan Perbankan Indonesia. Jakarta. Oktokber 2011.

BCA Learning Center. Produk Kredit Penjaminan. Jakarta. Desember 2011. 


\section{Tanggung Gugat Perdata Bank terhadap Klaim Bank Garansi Yang Dikeluarkan}

Youngky Yudho Pramono

Kebijakan Perkreditan Bank Central Asia. 2010. Manual Ketentuan Penyelamatan dan Penghapusan Kredit Versi 08. Jakarta. Desember.

Kitab Undang-Undang Hukum Perdata.

Mertokusumo, Sudikno. 2006. Penemuan Hukum (sebuah Pengantar). Liberty. Edisi Kedua (Cetakan Kedua). Yogyakarta.

Panduan Kerja Fungsi Operasi Kredit BCA, Terbitan September, 2007.

Peraturan Bank Indonesia Nomor: 7/2/PBI/2005 tanggal 20 Januari 2005, Tentang Penyelesaian Anggunan yang Diambil Alih.

Rahardjo, Satjipto. 2006. Ilmu Hukum. Citra Aditya Bakti. Bandung.

Soerkanto, Soerjono. 1983. Pengantar Penelitian Hukum. UII Press. Jakarta.
Sofwan, Sri Soedewi Masjchoen, 2007, Hukum Jaminan Di Indonesia Pokok-pokok Hukum Jaminan dan Jaminan Perorangan, Liberti, Yogyakarta.

Surat Keputusan Direksi Bank Indonesia Nomor: 23/ 88/KEP/DIR tentang pemberian Bank Garansi, tanggal 18 Maret 1991.

Susanto, Teguh. 2013. Liem Sioe Liong Kisah Orang Terkaya Di Indonesia dari Petani Hingga Menjadi Konglomerat. Buku Pintar. Yogyakarta.

Suyatno, Thomas. 2003. Kelembagaan Perbankan. Gramedia Pustaka Utama. Jakarta.

\section{How to cite:}

Pramono, Y. Yudho. 2017. Tanggung Gugat Perdata Bank Terhadap Klaim Bank Garansi yang Dikeluarkan. Jurnal Cakrawalah Hukum, 8(2). 